\title{
Information Communication Technology Use and Job Performance of Teachers at a Private International School in Uganda
}

\author{
Wilson Mugizi ${ }^{*}$, Christopher Mwujuka Amwine ${ }^{2}$ \\ ${ }^{1}$ Directorate of Postgraduate Studies and Research, Kampala International University Western Campus, Ishaka, Bushenyi, Uganda \\ ${ }^{2}$ American Refugee Committee, Kampala, Uganda \\ Email: *wilsonmugizi@kiu.ac.ug
}

How to cite this paper: Mugizi, W., \& Amwine, C. M. (2020). Information Communication Technology Use and Job Performance of Teachers at a Private International School in Uganda. Creative Education, 11, 166-181.

https://doi.org/10.4236/ce.2020.112012

Received: January 24, 2020

Accepted: February 24, 2020

Published: February 27, 2020

Copyright $\odot 2020$ by author(s) and Scientific Research Publishing Inc. This work is licensed under the Creative Commons Attribution International License (CC BY 4.0).

http://creativecommons.org/licenses/by/4.0/

\begin{abstract}
This study assessed the influence of information communication technology (ICT) use on job performance of teachers at a private International School in Kampala, Uganda. Specifically, the study assessed the influence of ICT enabled school administration, electronic information resources access and ICT enabled collaborative teaching and learning on job performance of teachers. Using the correlational research design, data were collected from teachers using a self-administered questionnaire. Descriptive results showed that performance of teachers was good and use of ICT enabled school administration, electronic information resources access, collaborative teaching and learning was high. Regression analysis revealed that while electronic information resources access had a positive and significant influence on job performance of teachers, ICT enabled school administration and ICT enabled collaborative teaching and learning had a positive but insignificant influence on performance of teachers. It was concluded that electronic information resources access is very essential for job performance of teachers but ICT enabled school administration and ICT enabled collaborative teaching are not critical for job performance of teachers. It was thus recommended that stakeholders in the education sector including the Ministry of Education, Directors of schools and head teachers should promote teachers' access to electronic information resources access giving less emphasis to ICT enabled school administration and ICT enabled collaborative teaching.
\end{abstract}

\section{Keywords}

Collaborative Teaching, Information Communication Technology, Job Performance of Teachers, School Administration, Resources Access 


\section{Introduction}

Teachers play the role of transforming socioeconomic conditions of society by educating children equipping them with skills, knowledge and habits for survival in the ever changing world (Amuche \& Kukwi, 2013). As the role of workers in production is similar to the role of machinery and other forces of production, teachers are required for the process of producing children's learning outcomes. Teachers have influence on not only test scores of students but also their social and emotional development, their behaviours, knowledge and critical thinking development (Blazar \& Kraft, 2017; Ginsburg, 2017). Therefore, effective performance of teachers is paramount for any society. Worldwide, the advent of information technology communication (ICT) was seen by many practitioners and policymakers as being important for improving performance of teachers (Olokoba, Abdullahi, \& Omosidi, 2014). Therefore, ICT applications have been used in administration and management in schools because of the belief that they facilitate administration activities from data storage to knowledge management and decision making (Ghavifekr, Afshari, Siraj, \& Seger, 2013). ICT promotes the sharing of valuable resources and collaborative teaching (Livingstone, 2012). Hammami (2016) indicates that ICT bridges forms of knowledge and literacy, and intersects places of learning including school removing the traditional barriers that existed before its advent in terms of access to books, writing and databases among others.

In the developed countries such as Britain, the USA and elsewhere, there has been a steady embedding of digital and networked technologies in the classroom, with widespread use of interactive whiteboards, virtual learning environments, educational computer games, and increasing reliance on internet application including email and e-learning (Bansal, 2016). However, opportunities for realising the benefits of using ICT in education face a number of challenges in developing countries especially in Africa. Access to ICT facilities is a major challenge facing most African countries, with a ratio of one computer to 150 students against the ratio of 1:15 students in the developed countries (Andiema, 2015). Especially in Sub-Saharan Africa, introducing ICT use into schools is largely influenced by availability and accessibility of ICT resources. Nevertheless, schools are increasingly getting equipped with computers for teaching, learning and administrative purposes; hence ICT connectivity is improving (Hennessy, Harrison, \& Wamakote, 2010). Therefore, this study assessed how ICT use in schools in developing countries, specifically in an international school in Kampala in Uganda influenced job performance of teachers. In particular, the study assessed how ICT enabled school administration, electronic information resources access and ICT enabled collaborative teaching and learning influenced job performance of teachers.

\section{Literature Review}

Theoretical Review. This study adopted the Task-Technology Fit (TTF) 
Theory advanced by Goodhue and Thompson (1995) to explain the relationship between ICT and job performance of teachers. TTF is the degree to which a technology assists an individual in performing his or her portfolio of task (Kim, Suh, Lee, \& Choi, 2010). TTF explains that information technology (IT) is more likely to produce benefits for an organisation if its capabilities more closely match the tasks to be performed (Ciganek, Jarupathirun, Ooppamai, \& Kerdpitak, 2009). TTF is higher when the functionality of a technology and the user's requirements are similar (Osang, 2015). With TTF, technologies are viewed as tools used by individuals in carrying out their tasks (Tripathi \& Jigeesh, 2015). Task characteristics of interest include those that might move a user to rely more heavily on certain aspects of the information technology. Thus, automation, sharing of resources, multi-tenancy, and remote implementation are the daily routine tasks of the organisation that are fulfilled (Obeidat \& Turgay, 2012). Performance impact occurs when the technology meets the users' needs and provides features that support the fit of the requirements of the task (Tripathi \& Jigeesh, 2015). Performance impacts relate to the accomplishment of tasks by an individual. Improved efficiency, effectiveness or quality implies higher performance. High task-technology fit improves not only performance but also the likelihood of utilisation, regardless of why the system is utilised (Gebauer, Shaw, \& Gribbins, 2010). TTF Theory indicates that selecting a technology that fits the activities of the organisation such as a school may enhance performance of activities by the individuals in the organizations. This theory therefore was the basis for investigating the influence of school based ICT applications on job performance of teachers.

Information Communication Technology and Job Performance of Teachers. Information Communication Technology (ICT) refers to a diverse set of technological tools and resources used to communicate, and to create, disseminate, store, and manage information (Bizi \& Shittu, 2014). ICT applications in schools include ICT enabled school administration, electronic information resources access and collaborative teaching and learning (Fraillon, Ainley, Schulz, Friedman, \& Gebhardt, 2014; Rana, Greenwood, \& Fox-Turnbull, 2019). ICT enabled administration encompasses ICT applications for control and verification, organising and managing in an organisation (Ghavifekr, Afshari, Siraj, \& Seger, 2013). In schools, ICT enabled administration is used for activities such as supervision, monitoring attendance, continuing professional development, pupil contact and colleagues contact (Selwood, 2004). Electronic information resources access concerns information resource via the internet including a wide range of products including electronic periodicals, CD-ROMs, mailing list and databases (Akpojotor, 2016). Electronic information resources access includes access to electronic information facilities and e-journals among others (Nazir, 2015).

ICT collaborative teaching and learning is about teaching and learning methods using ICT that involve teamwork between teachers and among students. 
Collaborative teaching and learning covers ICT lessons integration, sharing digital resources and computer use during lessons (Drossel, Eickelmann, \& Schulz-Zander, 2017). With respect to performance of teachers, this is the ability of teachers to combine relevant inputs for the enhancement of teaching and learning processes (Amin, ullah Shah, Ayaz, \& Atta, 2013). Job performance of teachers is about designing lessons, providing instruction based on those lessons, and designing and implementing classroom management strategies to maximise the efficacy of instructional lessons within a classroom's environment (Steinberg \& Garrett, 2016). Conceptually, Hanif and Pervez (2004) perceived job performance of teachers in terms of classroom teaching, management, discipline and regularity, and interpersonal relations. Below, literature review relates ICT applications namely, ICT enabled school administration, electronic information resources access and collaborative teaching and learning to job performance of teachers.

ICT enabled School Administration and Performance of Teachers. A number of scholars (Nwigbo \& Madhu, 2016; Olokoba, Abdullahi, \& Omosidi, 2014; Sabanci, Ozyildirim, \& Imsir, 2014; Selwood, 2004; Thakral, 2015) have reported the importance ICT enabled school administration. Nwigbo and Madhu (2016) reported that ICT helped in the management of large quantities and types of data hence saving time and energy. Such tasks included organising of assessments, the maintenance of library functions, the preparation of reports and the organisation of events. Thus, teachers' easily maintained grade books, compiled data bank of exam questions, carried out online inspection and correction of students work on their computers, keeping records, chronicles, and archives of all the above-mentioned events and proceedings with fast retrieval and easy access to any entry. Olokoba et al. (2014) found out that ICT helped in the management of information essential for efficient running of schools or institutions of learning. ICT solved the problems of receiving, storage and retrieval of vital data at any point in time. Sabanci et al. (2014) established that ICT use eased classroom management, helped saving time, provided more opportunities for more activities, limited non-disciplinary behaviours of the students and encouraged leadership role of the teacher. Consequently, ICT use helps teachers taught more efficiently, attracted students' willingness to learn and ease classroom management processes.

Further, Selwood (2004) revealed that ICT reduced workload and improved the quality of work although there was need further training because actual use of ICT for administration and management levels was quite low. Thakral (2015) established that ICT was a tool for training and supporting teachers, regardless of geographical dispersion. Accordingly, ICT helped teachers to have access to more and better educational content, aid in routine administrative tasks, provide models and simulations of effective teaching practices, and enable learner support networks, and in real time or asynchronously. While the literature above shows that scholars have made significant effort to relate ICT enabled school 
administration and performance of teachers, none of the studies was carried out in the context of a school in Uganda. This contextual gap made it imperative for this study to be carried out in the context of a school in Uganda to test the hypothesis that:

$\mathrm{H}_{1}$ : ICT enabled school administration influences job performance of teachers.

Electronic Information Resources Access and Performance of Teachers. Different scholars (Bhukuvhani, Chiparausha, \& Zuvalinyenga, 2012; Ibieta, Hinostroza, Labbé, \& Claro, 2017; Nwigbo \& Madhu, 2016; Sangrà \& González-Sanmamed, 2010; Shamim \& Raihan, 2016) have studied the influence of electronic information resources access and performance of teachers. For example, Bhukuvhani et al. (2012) found out that access to electronic resources helped teachers to carry out research and prepare for their students. The use of electronic information resources positively and significantly affected their work as evidenced by the results. Ibieta et al. (2017) established that teachers that used ICT more frequently for class preparation improved their content delivery in the classrooms. Nwigbo and Madhu (2016) revealed that access to e-resources enabled teachers to access data files during lesson preparations and research helping them to carry out effective teaching because of access to high quality resources. Teachers accessed a variety of information sources preparing and updating daily lessons and plans.

Sangrà and González-Sanmamed (2010) revealed that ICT favoured several teaching and learning processes and the improvement of teaching and learning processes was especially higher in the schools that had integrated ICT as an innovation factor. In their study, Shamim and Raihan (2016) found out that integration of ICTs in teaching and learning process made teaching and learning very easy, interesting, and time saving than that of traditional way of teaching-learning. ICTs were essential for enhancing the process of teaching-learning. However, whereas the literature above revealed that scholars have expended effort to relate electronic information resources access and performance of teachers, as the studies suggest, none of the studies was done in the context of Uganda. For instance, Bhukuvhani et al. (2012) carried out their study in Zimbabwe, Ibieta et al. (2017) in Chile, Sangrà and González-Sanmamed (2010) in Spain, and Shamim and Raihan (2016) in Bangladesh. Hence, differences in technological levels may hinder generalisation of results on schools in Uganda. This contextual gap made it crucial to test the hypothesis to the effect that:

$\mathrm{H}_{2}$ : Electronic information resources access influences job performance of teachers.

ICT Enabled Collaborative Teaching and Learning and Performance of Teachers. Scholars (García-Valcárcel, Basilotta, \& Salamanca, 2014; Ibieta et al., 2017; Sharma, Bassi, \& Sharma, 2011) have analysed the influence of ICT enabled collaborative teaching and learning on performance of teachers. For example, García-Valcárcel et al. (2014) reported that ICT had great potential for 
enhancing collaborative activities among students and for developing highly relevant generic skills. Ibieta et al. (2017) found out that teachers used communication tools to communicate with colleagues and students exchanging information. Noor-Ul-Amin (2013) established that adoption and use of ICTs in education had a positive impact on teaching, learning, and research. ICT increased flexibility so that learners can access the education regardless of time and geographical barriers through collaborative teaching and learning. Roy (2012) revealed that ICT-enhanced learning environment facilitated active collaborative, creative, integrative and evaluative learning. Sharma et al. (2011) reported that ICT helped facilitate the transaction between producers and users by keeping the students updated and enhancing teachers capacity and ability fostering a live contact between the teacher and the student through e-mail, e-learning, web-based learning including internet, intranet, extranet, CD-ROM, TV audio-videotape. However, as the studies above suggest, none was carried out in the context of a school Uganda. Therefore, this study in context of Uganda tested the hypothesis to the effect that:

H3: ICT enabled collaborative teaching and learning influences job performance of teachers.

\section{Methods}

\section{Sample and Procedure}

The sample comprised 65 primary teachers of an international private school in Kampala in central Uganda. The study employed a correlational research design to establish the relationship between Information Communication Technology Use (independent variable) and Job Performance of Teachers (dependent variable). Hence data were collected using a questionnaire survey. Since the population of the school was small, the study planned to study all the 70 teachers but appropriate data were collected from 65 teachers hence the sample for the study. In the collection of data ethical issues were given paramount significance. Therefore, the researcher obtained informed consent of the respondents, guaranteed their anonymity and confidentiality. Respect for privacy was also observed and the researcher ensured honesty in the presentation, analysis and interpretation of the results by strictly basing them on the data collected.

Instrument. The instrument used to collect data was a self-administered questionnaire ( $\mathrm{SAQ}$ ) since the study adopted the quantitative approach. The SAQ comprised sections namely A, B and C. Section A was on the background characteristics of the respondents with questions on gender, age category, education level of the respondents, teaching experience and the responsibility of the teachers in the school. Section B was on the dependent variable (job performance of teachers) and section $\mathrm{C}$ on the independent variable (information communication technology use) with items adopted from instruments used by earlier. Job performance of teachers was studied as a multi-dimensional construct in terms of teaching, management, discipline and regularity and interpersonal 
relations performance (25 items $=4,5,6$ and 6 items respectively with overall $\alpha$ $=0.81$ ) (Amin et al., 2013). Information communication technology use was looked at in terms of ICT enabled school administration (5 items $\alpha=$ ) (Baek, Jung, \& Kim, 2008), electronic information resources access (Alahakoon \& Chiran, 2015) and collaborative teaching and learning (Cano \& Garcia, 2013). The question items on the dependent and independent variables were scaled using the five-point Likert scale with code 1 as the worst case scenario (strongly disagree) through the maximum of code 5 as the best case scenario (Strongly agree).

Data Management and Analysis. Data management involved data processing through which all the questionnaires were coded to enter them into the computer using the Statistical Package for Social Sciences (SPSS). The data were then summarised using frequency tables to identify which helped in identifying errors and collecting them. To confirm the scientific validity of the data, Factor Analysis was carried out. Thereafter, reliability tests for the constructs were carried using Cronbach Alpha ( $\alpha$ ). Validity and reliability results for the different constructs are presented in appropriate tables under the results section. Data were then analysed using descriptive and inferential analyses. Descriptive analysis involved calculating of means while inferential analyses involved carrying out of correlation and regression analyses. The results on the same follow in the next section.

\section{Results}

Demographic Characteristics. The results in Table 1 show that the typical respondent was female (69.2\%), aged 30 - 39 years $(43.1 \%)$, held a bachelor's degree $(41.5 \%)$, had less than five years' experience $(84.6 \%)$, and was learning support assistant.

Job Performance of Teachers. Under this subsection, the concept of job performance of teachers was studied in terms of classroom teaching, management of students, discipline and regularity and interpersonal relations. Frequencies, percentages, means, factor loadings and Cronbach's alpha ( $\alpha$ ) results on job performance of teachers' constructs were as in Table 2.

Table 2 reveals that teachers rated their performance as good (overall means for classroom teaching $=4.08$, management of students $=4.31$, discipline and regularity $=4.18$ and interpersonal relations $=4.59$ all corresponding to agreed) . Factor Analysis indicated that the items for classroom teaching, discipline and regularity and interpersonal relations could be reduced to one factor but those for management of students could be reduced to two factors. With factor loadings of 0.5 and above considered strong (Pedrosa, Rodrigues, Padilha, Gallani, \& Alexandre, 2016), the items measuring the various constructs were considered valid. The Cronbach's alphas $=0.941,0.764,0.910$ and 0.954 for the respective components of job performance of teachers were above the acceptable level = 0.70 (Taber, 2018). The overall Cronbach's Alpha $=0.959$ for measure of job 
Table 1. Respondents' background characteristics.

\begin{tabular}{|c|c|c|c|}
\hline Item & Categories & Frequency & Percent \\
\hline \multirow{3}{*}{ Gender } & Male & 20 & 30.8 \\
\hline & Female & 45 & 69.2 \\
\hline & Total & 65 & 100.0 \\
\hline \multirow{4}{*}{ Age Groups } & $20-29$ years & 27 & 41.5 \\
\hline & $30-39$ years & 28 & 43.1 \\
\hline & $40-49$ years & 10 & 15.4 \\
\hline & Total & 65 & 100.0 \\
\hline \multirow{4}{*}{ Education level } & Diploma & 21 & 32.3 \\
\hline & Bachelor's Degree & 27 & 41.5 \\
\hline & Postgraduate qualification & 17 & 26.2 \\
\hline & Total & 65 & 100.0 \\
\hline \multirow{3}{*}{ Experience } & Less than 5 years & 55 & 84.6 \\
\hline & $5-10$ years & 10 & 15.4 \\
\hline & Total & 65 & 100.0 \\
\hline \multirow{5}{*}{ Responsibility } & Subject Teachers & 5 & 7.7 \\
\hline & Class teacher & 12 & 18.5 \\
\hline & Learning Support Assistant & 38 & 58.5 \\
\hline & Senior administrator & 10 & 15.4 \\
\hline & Total & 65 & 100.0 \\
\hline
\end{tabular}

Table 2. Job performance of teachers.

\begin{tabular}{cclc}
\hline Classroom Teaching & Mean & Factor loadings & $\boldsymbol{\alpha}$ \\
\hline Prepare for lessons comprehensively & 3.98 & 0.949 & 0.941 \\
Make difficult lessons easy for the pupils & 4.00 & 0.947 & \\
Use different methods of teaching & 4.25 & 0.944 & \\
Respond to pupils questions to their satisfaction & 4.09 & 0.865 & \\
Total Mean & $\mathbf{4 . 0 8}$ & & $\mathbf{a}$ \\
\hline Management of students & Mean & Factor loadings & 0.764 \\
Make pupils perform various learning activities & 4.48 & 0.895 & \\
Involve pupils in co-curricular activities & 4.26 & 0.813 & \\
Direct pupils in every sphere of school life & 4.18 & 0.799 & \\
Accept responsibilities from my supervisors & 4.55 & 0.715 & $\mathbf{\alpha}$ \\
Carry out management responsibilities & 4.08 & & 0.781 \\
Total Mean & $\mathbf{4 . 3 1}$ & & \\
\hline Discipline and regularity & Mean & Factor loadings & \\
\hline Make pupils fulfil all curriculum requirements & 4.25 & 0.934 & \\
\hline
\end{tabular}


Continued

\begin{tabular}{|c|c|c|c|}
\hline Maintain discipline of pupils & 4.32 & 0.892 & \\
\hline I effectively enforce school rules and regulations & 4.17 & 0.849 & \\
\hline Ensuring that pupils come to school regularly & 3.82 & 0.831 & \\
\hline Attend to my class on scheduled time & 4.25 & 0.829 & \\
\hline Devise measures for maintaining discipline & 4.28 & 0.692 & \\
\hline Total Mean & 4.18 & & \\
\hline Interpersonal relations & Mean & Factor loadings & $a$ \\
\hline Maintain professional relations with colleagues and pupils & 4.57 & 0.936 & 0.954 \\
\hline Maintain good relations with my pupils parents & 4.75 & 0.926 & \\
\hline Enjoy good relations with my colleagues & 4.66 & 0.921 & \\
\hline Solve problem that arise between me and colleagues & 4.57 & 0.902 & \\
\hline Request for necessary support from my colleagues & 4.49 & 0.898 & \\
\hline Work with colleagues to accomplish school tasks & 4.49 & 0.891 & \\
\hline Total Mean and Overall Cronbach's Alpha & 4.59 & & 0.959 \\
\hline
\end{tabular}

performance of teachers suggested that the items for the four components were reliable measures.

Information Communication Technology Use. Information communication technology (ICT) use was studied using three constructs namely; ICT enabled school administration, electronic information resources access and collaborative teaching. The results on ICT use included frequencies, percentages and means. For each construct of ICT use, factor loadings and Cronbach's alpha (a) results are presented indicating the validity and reliability of the results. The results on ICT use constructs are as presented in Table 3.

Table 3 shows that teachers rated ICT use as good (overall means for ICT enabled school administration $=3.89$, electronic information resources access $=$ 4.20 and ICT collaborative teaching $=4.02$ all corresponding to agreed). Factor Analysis showed that while items for ICT enabled school administration could be reduced to two factors, items for electronic information resources access and ICT collaborative teaching could be reduced to one factor. Considering factor loadings of 0.5 and above strong, the items measuring the various constructs were considered valid. The Cronbach's alphas $=0.714,0.820$ and 0.862 for the respective ICT use constructs were above the acceptable level $=0.70$. The overall Cronbach's Alpha $=0.854$. This implied that the items for the three components for ICT use were reliable measures.

Correlation between ICT Use and Job performance of Teachers. To find out whether there was a relationship between ICT use and job performance of teachers, at the preliminary level a correlation analysis was carried out. The results are presented in Table 4.

The results in Table 4 indicate that while ICT school administration applications $(r=0.242, p=0.052>0.05)$ had a positive but insignificant relationship 
Table 3. Information communication technology use.

\begin{tabular}{|c|c|c|c|}
\hline ICT enabled school administration & Mean & Factor loadings & a \\
\hline Can alert staff to signs of bad or inappropriate behaviour using technologies & 4.06 & 0.867 & 0.714 \\
\hline Use a computer to monitor student/pupils' activities in class and other areas & 3.46 & 0.822 & \\
\hline Use computer to access a student's/pupil's profile for easy follow up & 3.63 & 0.773 & \\
\hline The school has installed surveillance gadgets to follow up on students/pupils and teachers & 3.98 & 0.645 & \\
\hline Monitor students/pupils activity in real time & 4.34 & 0.868 & \\
\hline Total Mean & 3.89 & & \\
\hline Electronic information resources access & Mean & Factor loadings & $\alpha$ \\
\hline Easily get electronic information useful for teaching and learning & 4.26 & 0.907 & 0.820 \\
\hline Use Internet for research purposes in preparation for my lessons & 4.43 & 0.884 & \\
\hline Access teaching materials using online public access catalogue & 4.26 & 0.875 & \\
\hline The school has subscribed to sources that provide information for teaching and learning & 4.32 & 0.820 & \\
\hline Use internet to obtain good teaching aids & 4.37 & 0.767 & \\
\hline Use Internet to read newspapers on line & 3.58 & 0.947 & \\
\hline Total Mean & 4.20 & & \\
\hline ICT collaborative teaching & Mean & Factor loadings & a \\
\hline Participate in chat sessions to discuss teaching and learning activities in the school & 3.66 & 0.899 & 0.862 \\
\hline $\begin{array}{l}\text { The online interface has created a team environment with members sharing important ideas and } \\
\text { guiding one another's teaching }\end{array}$ & 4.18 & 0.870 & \\
\hline Have been able to improve my teaching because of online collaboration & 4.09 & 0.843 & \\
\hline Give and receive help and assistance online & 4.14 & 0.756 & \\
\hline Total Mean and Overall Cronbach's Alpha & 4.02 & & 0.854 \\
\hline
\end{tabular}

Table 4. Correlation between ICT use and job performance of teachers.

\begin{tabular}{|c|c|c|c|c|}
\hline & $\begin{array}{c}\text { Job Performance } \\
\text { of Teachers }\end{array}$ & $\begin{array}{c}\text { ICT School Administration } \\
\text { Applications }\end{array}$ & $\begin{array}{l}\text { Electronic Information } \\
\text { Resources Access }\end{array}$ & $\begin{array}{l}\text { Collaborative Teaching } \\
\text { and Learning }\end{array}$ \\
\hline Job Performance of Teachers & 1 & & & \\
\hline \multirow{2}{*}{$\begin{array}{l}\text { ICT School Administration } \\
\text { Applications }\end{array}$} & 0.242 & 1 & & \\
\hline & 0.052 & & & \\
\hline \multirow{2}{*}{$\begin{array}{l}\text { Electronic Information Resources } \\
\text { Access }\end{array}$} & $0.571^{\star *}$ & $0.354^{* *}$ & 1 & \\
\hline & 0.000 & 0.004 & & \\
\hline \multirow{2}{*}{$\begin{array}{l}\text { Collaborative Teaching and } \\
\text { Learning }\end{array}$} & $0.309^{*}$ & $0.420^{* *}$ & $0.482^{* *}$ & 1 \\
\hline & 0.012 & 0.000 & 0.000 & \\
\hline
\end{tabular}

with job performance of teachers, electronic information resources access $(\mathrm{r}=$ $0.571, p=0.000<0.05)$ and collaborative teaching and learning $(\mathrm{r}=0.309, p=$ $0.012<0.05)$ had a positive and significant influence on job performance of teachers. Therefore, the results suggested that at preliminary level, hypothesis 
One $\left(\mathrm{H}_{1}\right)$ was rejected but Hypotheses Two and Three $\left(\mathrm{H}_{2}\right.$ and $\left.\mathrm{H}_{3}\right)$ were supported.

Regression of Job Performance of Teachers on Information Communication Technology Use. At the confirmatory level, to find out whether job performance of teachers was influenced by information communication technology use elements, namely ICT enabled school administration, electronic information resources access and ICT collaborative teaching and learning, a multiple regression was carried out. The results were as in Table 5 .

The results in Table 5 show that ICT use explained $29.6 \%$ of the variation in job performance of teachers (adjusted $\mathrm{R}^{2}=0.296$ ). This means that $70.4 \%$ was accounted for by other factors not considered in this model. The regression model was good/significant $(\mathrm{F}=9.963, \mathrm{p}=0.000<0.05)$. However, of the three factors, only electronic information resources access $(\beta=0.543, p=0.000<0.05)$ had a positive and significant influence on job performance of teachers while ICT enabled school administration $(\beta=0.094, p=0.759>0.05)$ and ICT collaborative teaching and learning $(\beta=0.032, p=0.801>0.05)$ had a positive but insignificant influence on job performance of teachers. Therefore, while Hypothesis Two $\left(\mathrm{H}_{2}\right)$ was supported, Hypotheses One and Third $\left(\mathrm{H}_{1}\right.$ and $\left.\mathrm{H}_{3}\right)$ were rejected.

\section{Discussion}

The findings of the study revealed that ICT enabled school administration had a positive but insignificant influence on job performance of teachers. This finding was inconsistent with the findings made by previous scholars. For instance, Nwigbo and Madhu (2016) reported that ICT helped in the management of large quantities and types of data hence saving time and energy. Similarly, Olokoba et al. (2014) indicated that ICT solved the problems of receiving, storage and retrieval of vital data at any point in time. Also, Selwood (2004) established that ICT reduced workload and improved the quality of work which thus enhanced job performance of teachers. Still, Sabanci et al. (2014) revealed ICT use helped teachers to teach more efficiently. Thakral (2015) found out ICT helped teachers to have access to more and better educational content, aid in routine administrative tasks, provide models and simulations of effective teaching practices, and enabled learner support networks, and in real time or asynchronously. Therefore, with the finding of the study inconsistent with the findings of previous

Table 5. Regression of job performance of teachers on ICT use.

\begin{tabular}{ccc}
\hline & Standardised Coefficients & Significance \\
\hline ICT use & Beta $(\beta)$ & $(\mathrm{p})$ \\
ICT enabled school administration & 0.094 & 0.759 \\
Electronic information resources access & 0.543 & 0.000 \\
ICT collaborative teaching and learning & 0.032 & 0.801 \\
\hline
\end{tabular}

Adjusted $\mathrm{R}^{2}=0.296 ; \mathrm{F}=9.963, p=0.000$. 
scholars, it can be deduced that ICT enabled school administration was not the paramount factor for job performance of teachers in the context of schools Uganda.

Nevertheless, the finding to the effect that electronic information resources access had a positive and significant influence on job performance of teachers agreed with the findings of previous scholars. For example, Bhukuvhani et al. (2012) reported that the use of electronic information resources positively and significantly affected teachers work performance. Likewise, Ibieta et al. (2017) established that teachers that used ICT more frequently for class preparation improved their content delivery in the classrooms. Also, Nwigbo and Madhu (2016) revealed that access to e-resources helped teachers to carry out effective teaching through access to high quality resources. Further still, Sangrà and González-Sanmamed (2010) revealed that ICT favoured several teaching and learning processes improving teaching processes. This was also supported by the study by Shamim and Raihan (2016) with found out that integration of ICTs in teaching and learning process made teaching very easy. Therefore, with the finding of the study agreeing with the findings of previous scholars, it can be inferred that electronic information resources access are essential for job performance of teachers.

Lastly, the finding that ICT collaborative teaching and learning had a positive but insignificant influence on job performance of teachers was contrary to the findings of previous scholars. For example, García-Valcárcel et al. (2014) revealed that ICT had great potential for enhancing collaborative activities most likely influencing job performance. Relatedly, Ibieta et al. (2017) reported that teachers used communication tools to communicate with colleagues and students exchanging information. Further, Noor-Ul-Amin (2013) established that adoption and use of ICTs in education had a positive impact on teaching, learning, and research. Also, Roy (2012) revealed that ICT-enhanced learning environment facilitated active collaborative, creative, integrative and evaluative learning. Sharma et al. (2011) revealed that ICT helped facilitate the transaction between producers and users by keeping the students updated and enhancing teachers capacity and ability fostering a live contact between the teacher and the student through e-mail, e-learning, web-based learning including internet, intranet, extranet, CD-ROM, TV audio-videotape. However, with the finding of the study being contrary to the findings of previous scholars, it can be conjectured that ICT collaborative teaching and learning is not the most important factor for job performance of the study.

\section{Conclusion}

Electronic information resources access is very essential for job performance of teachers. This is because teachers are able to access electronic information useful for teaching, are able to easily make research in preparation for lessons, are helped to obtain good teaching aids and even read newspapers online. However, 
ICT enabled school administration has limited contribution to job performance of teachers. That is ICT alerts, ICT enabled monitoring of pupils' activities and access to pupil's profiles did not impact greatly on the job performance of teachers. Finally, ICT enabled collaborative teaching was not very crucial for the job performance. This is because chat sessions between teachers, online interface and collaboration and giving and receiving help and assistance online did not significantly impact on job performance of teachers. Therefore, it was recommended that stakeholders in the education sector including the Ministry of Education, Directors of schools and head teachers should promote teachers' access to electronic information resources access giving less emphasis to ICT enabled school administration and ICT enabled collaborative teaching.

\section{Conflicts of Interest}

The authors declare no conflicts of interest regarding the publication of this paper.

\section{References}

Akpojotor, L. O. (2016). Awareness and Usage of Electronic Information Resources among Postgraduate Students of Library and Information Science in Southern Nigeria. Library Philosophy and Practice (E-Journal). https://digitalcommons.unl.edu/libphilprac/1408/

Alahakoon, C. N., \& Chiran, C. (2015). Development and Validation of the Electronic Information Resources Usage Scale. 10th International CALIBER-2015 HP University and IIAS, Shimla, Himachal Pradesh, 12-14 March 2015.

Amin, M., ullah Shah, R., Ayaz, M., \& Atta, M. A. (2013). Teachers' Job Performance at Secondary Level in Khyber Pakhyunkhwa, Pakistan. Gomal University Journal of Research, 29, 100-104.

Amuche, C. I., \& Kukwi, I. J. (2013). An Assessment of Stakeholders' Perception of the Implementation of Universal Basic Education in North-Central Geo-Political Zone of Nigeria. Journal of Education and Practice, 4, 158-167.

Andiema, N. C. (2015). Challenges of Adoption of Information Communication Technology on Teaching and Learning in Public Preschools in North Rift Region, Kenya. International Journal of Economics, Commerce and Management, 3, 61-74.

Baek, Y., Jung, J., \& Kim, B. (2008). What Makes Teachers Use Technology in the Classroom? Exploring the Factors Affecting Facilitation of Technology with a Korean Sample. Computers \& Education, 50, 224-234.

https://doi.org/10.1016/j.compedu.2006.05.002

Bansal, D. (2016). Benefits of ICT in Education. Bhartiyam International Journal of Education \& Research, 5, 1-8.

Bhukuvhani, C., Chiparausha, B., \& Zuvalinyenga, D. (2012). Effects of Electronic Information Resources Skills Training for Lecturers on Pedagogical Practices and Research Productivity. International Journal of Education and Development Using ICT, 8, 16-28.

Bizi, A. M., \& Shittu, F. (2014). Information and Communication Technology (ICT) and Education. Journal of Educational and Social Research, 4, 88-91.

https://doi.org/10.5901/jesr.2014.v4n7p88 
Blazar, D., \& Kraft, M. A. (2017). Teacher and Teaching Effects on Students' Attitudes and Behaviours. Educational Evaluation and Policy Analysis, 39, 146-170. https://doi.org/10.3102/0162373716670260

Cano, E. V., \& Garcia, M. (2013). ICT Strategies and Tools for the Improvement of Instructional Supervision. The Virtual Supervision. Turkish Online Journal of Educational Technology-TOJET, 12, 77-87.

Ciganek, A. P., Jarupathirun, S., Ooppamai, P., \& Kerdpitak, C. (2009). Improving Performance through Task Technology fit: A Case Study. International Conference on IT to Celebrate S. Charmonman's 72nd Birthday, Thailand, March 2009.

Drossel, K., Eickelmann, B., \& Schulz-Zander, R. (2017). Determinants of Teachers' Collaborative Use of Information and Communications Technology for Teaching and Learning: A European Perspective. European Educational Research Journal, 16, 781-799. https://doi.org/10.1177/1474904116655811

Fraillon, J., Ainley, J., Schulz, W., Friedman, T., \& Gebhardt, E. (2014). School Environments for Teaching and Learning Computer and Information Literacy. In Preparing for Life in a Digital Age (pp. 167-193). Cham: Springer.

https://doi.org/10.1007/978-3-319-14222-7 7

García-Valcárcel, A., Basilotta, V., \& Salamanca, C. L. (2014). ICT in Collaborative Learning in the Classrooms of Primary and Secondary Education. Media Education Research Journal, 42, 65-74. https://doi.org/10.3916/C42-2014-06

Gebauer, J., Shaw, M. J., \& Gribbins, M. L. (2010). Task-Technology Fit for Mobile Information Systems. Journal of Information Technology, 25, 259-272.

https://doi.org/10.1057/jit.2010.10

Ghavifekr, S., Afshari, M., Siraj, S., \& Seger, K. (2013). ICT Application for Administration and Management: A Conceptual Review. Procedia-Social and Behavioural Sciences, 103, 1344-1351. https://doi.org/10.1016/j.sbspro.2013.10.705

Ginsburg, M. (2017). Teachers as Human Capital or Human Beings? USAID’s Perspective on Teachers. Current Issues in Comparative Education, 20, 6-30.

Goodhue, D. L., \& Thompson, R. L. (1995). Task-Technology Fit and Individual Performance. MIS Quarterly, 19, 213-236. https://doi.org/10.2307/249689

Hammami, A. (2016). ESL Teacher Profiles of ICT Integration in their Classroom Practices and Assessment Activities: A Portrait Viewed through the lens of Some Quebec Teachers' Social Representations. Doctoral Dissertation, Southern Quebec, Canada: Université De Sherbrooke. http://www.semanticscholar.org

Hanif, R., \& Pervez, S. (2004). Development and Validation of Teachers' Job Performance Scale. Pakistan Journal of Psychological Research, 19, 89-104. https://doi.org/10.1037/t68826-000

Hennessy, S., Harrison, D., \& Wamakote, L. (2010). Teacher Factors Influencing Classroom Use of ICT in Sub-Saharan Africa. Itupale Online Journal of African Studies, 2, 39-54.

Ibieta, A., Hinostroza, J. E., Labbé, C., \& Claro, M. (2017). The Role of the Internet in Teachers' Professional Practice: Activities and Factors Associated with Teacher Use of ICT inside and outside the Classroom. Technology, Pedagogy and Education, 26, 425-438. https://doi.org/10.1080/1475939X.2017.1296489

Kim, T., Suh, Y. K., Lee, G., \& Choi, B. G. (2010). Modelling Roles of Task-Technology Fit and Self-Efficacy in Hotel Employees' Usage Behaviours of Hotel Information Systems. International Journal of Tourism Research, 12, 709-725. https://doi.org/10.1002/jtr.787 
Livingstone, S. (2012). Critical Reflections on the Benefits of ICT in Education. Oxford Review of Education, 38, 9-24. https://doi.org/10.1080/03054985.2011.577938

Nazir, T. (2015). Use and Adequacy of e-Resources by the Research Scholars and Students of the University of Kashmir in Science \& Social Science Faculties: A Case Study. Brazilian Journal of Information Science: Research Trends, 9. https://doi.org/10.36311/1981-1640.2015.v9n1.08.p135

Noor-Ul-Amin, S. (2013). An Effective Use of ICT for Education and Learning by Drawing on Worldwide Knowledge, Research and Experience: ICT as a Change Agent for Education (A Literature Review). Scholarly Journal of Education, 2, 38-45.

Nwigbo, S., \& Madhu, B. K. (2016). Impact of ICT on the Teaching and Learning Process. IOSR Journal of Mobile Computing \& Application (IOSR-JMCA), 3, 1-7.

Obeidat, M. A., \& Turgay, T. (2012). Empirical Analysis for the Factors Affecting the Adoption of Cloud Computing Initiatives by Information Technology Executives. Journal of Management Research, 5, 152-178. https://doi.org/10.5296/jmr.v5i1.2764

Olokoba, A. A., Abdullahi, A. M., \& Omosidi, S. A. (2014). Impact of Information Communication Technology (ICT) on the Management and Performance of Secondary School Teachers in Kwara State, Nigeria. International Journal of Education Learning and Development, 2, 60-67.

Osang, F. B. (2015). Task Technology Fit and Lecturers Performance Impacts: The Technology Utilization, Satisfaction and Performance (TUSPEM) Dimension. International Journal of Computer Science Issues (IJCSI), 12, 232-239.

Pedrosa, R. B. S., Rodrigues, R. C. M., Padilha, K. M., Gallani, M. C. B. J., \& Alexandre, N. M. C. (2016). Factor Analysis of an Instrument to Measure the Impact of Disease on Daily Life. Revista Brasileira de Enfermagem, 69, 650-657.

Rana, K., Greenwood, J., \& Fox-Turnbull, W. (2019). Implementation of Nepal's Education Policy in ICT: Examining Current Practice through an Ecological Model. Electronic Journal of Information Systems in Developing Countries, e12118 https://doi.org/10.1002/isd2.12118

Roy, N. K. (2012). ICT-Enabled Rural Education in India. International Journal of Information and Education Technology, 2, 525-529. https://doi.org/10.7763/IJIET.2012.V2.196

Sabanci, A., Ozyildirim, G., \& Imsir, R. (2014). The Effect of ICT Usage on the Classroom Management: A Case Study in Language Teaching. International Review of Social Sciences and Humanities, 7, 232-245.

Sangrà, A., \& González-Sanmamed, M. (2010). The Role of Information and Communication Technologies in Improving Teaching and Learning Processes in Primary and Secondary Schools. ALT-J, Research in Learning Technology, 18, 207-220.

https://doi.org/10.1080/09687769.2010.529108

Selwood, I. (2004). Primary School Teachers' Use of ICT for Administration and Management. In IFIP Conference on Information Technology in Educational Management (pp. 11-22). Boston, MA: Springer. https://doi.org/10.1007/0-387-24045-4 2

Shamim, M. R. H., \& Raihan, M. A. (2016). Effectiveness of Using ICTs to Promote Teaching and Learning in Technical Education: Case of Bangladesh. International Journal of Vocational and Technical Education, 8, 12-19.

Sharma, A., Bassi, D., \& Sharma, S. (2011). Role of ICT in the Process of Teaching and Learning. Journal of Education and Practice, 2, 1-5.

Steinberg, M. P., \& Garrett, R. (2016). Classroom Composition and Measured Teacher Performance: What Do Teacher Observation Scores Really Measure? Educational 
Evaluation and Policy Analysis, 38, 293-317. https://doi.org/10.3102/0162373715616249

Taber, K. S. (2018). The Use of Cronbach's Alpha When Developing and Reporting Research Instruments in Science Education. Research in Science Education, 48, 1273-1296. https://doi.org/10.1007/s11165-016-9602-2

Thakral, P. (2015). Role of ICT in Professional Development of Teachers. Learning Community, 6, 127-133. https://doi.org/10.5958/2231-458X.2015.00011.1

Tripathi, S., \& Jigeesh, N. (2015). Task-Technology Fit (TTF) Model to Evaluate Adoption of Cloud Computing: A Multi-Case Study. International Journal of Applied Engineering Research, 10, 9185-9200. 